\title{
Health costs of the Gulf war
}

\author{
Ian Lee, Andy Haines
}

Although much has been written about the Gulf conflict, comparatively little attention has been paid to the medical aspects of the conflict and to the overall balance between the costs and benefits. As the situation continues to evolve in Iraq it becomes clearer that some of the short term effects of the war given so much publicity will be overshadowed by the medium and long term adverse consequences. The overall balance between the costs and benefits of war has to be assessed in terms of its impact on human health, human rights, the environment, the economy, and the long term political balance in the region. This paper considers primarily the impacts on health but also touches on other fields.

\section{Estimates of short term casualties}

It has been difficult to find precise estimates of Iraqi military casualties. Figures of 100000 and over have been mentioned by several sources (Center for Defence Information, Washington, DC, and International Institute of Strategic Studies, London, personal communications).' The American defence secretary, Richard Cheney, said in February that $15 \%$ of Iraqi troops $(80000)$ were dead or seriously wounded. Subsequent estimates lowered this figure to between 20000 and $25000,{ }^{2}$ which suggests a fatality rate of one death for each four tons of explosive used by the Coalition (total 88500 tons). Both sides may, however, have a vested interest in minimising casualties from the immediate effects of war. In the retreat of the Iraqi troops from Kuwait a massive convoy of Iraqi vehicles was destroyed. A reporter, Michael Kelly, describing the scene on the coastal road from Kuwait to Iraq said: "For a 50 or 60 mile stretch from just north of Jahra to the Iraqi border, the road was littered with exploded and roasted vehicles, charred and blown up bodies." An estimate of 25000 Iraqi military dead from this acti in alone was circulating in the army. ${ }^{1}$ In addition, so 2 \& 2000 Iraqi soldiers died in the post-ceasefire attack on a large Iraqi convoy which fired rockets at a platoon of the 24th Infantry Division. Many of the Iraqi troops killed or wounded in the first and second lines of defence were forced conscripts from the Kurdish and Shi'ite ethnic groups oppressed by Saddam Hussein.

Civilian casualties attributable directly to the war were estimated as 5000-15000.' The United Nations' Ahtisaari report of 28 March estimated that 9000 homes were destroyed or damaged beyond repair during the war. ${ }^{3}$ Dr Ibrahim Al-Noore, head of the Iraqi Red Crescent, estimated that as early as 6 February Coalition bombing had caused 6000-7000 civilian deaths and that there had been a further 6000 deaths resulting from contaminated water and destruction of medical services and food stores. ${ }^{+}$The Kurdish commander, Masoud Barzani, was quoted as saying that there had been 3000 civilian casualties in the northern town of Kirkuk alone, and 300 casualties from a raid on an Iraqi helicopter base sited close to a Kurdish camp at Harir.'

The Coalition forces are reported to have had a total of 343 dead. In the case of Israel, according to reports passed by the military censor, 39 Scud missiles caused 13 deaths, 200 injuries, and damage to 4000 buildings. ${ }^{6}$

American and allied aircraft averaged 2500 combat sorties daily, including more than 1000 bombing missions a day. Airforce Secretary Donald Rice said that air to ground strikes were roughly $1 \%$ of the bombs that were dropped in Vietnam from 1961-72 ( 6.2 million tons). Nevertheless, the rate of tonnage dropped (63000 tons per month in the Gulf war) was more than that in the Vietnam war (34000 tons per month) or the Korean war (22000 tons per month). Air power paralysed Iraq strategically, operationally, and tactically. The contrast between detailed figures of bombs dropped and exact quantities of military material destroyed but nebulous estimates of human casualties is striking.

\section{Mortality and morbidity soon after the war}

About 1.8 million refugees, mainly Kurds, were displaced to camps on the Iranian border (1-1.3 million) and the Turkish border (400000-700 000). Shi'ite refugees attempting to escape atrocities by Iraqi troops fled to the marshes in southern Iraq, at the time of writing between 30000 and 100000 were said to be surrounded by Iraqi troops. Death rates among Kurdish refugees were reported as high as nearly 1000 babies dying each day from exposure, according to Iranian government officials. In late April the United Nations High Commission for Refugees stated that on the Turkish border "respiratory and intestinal diseases as well as exposure are mainly responsible for mortality rates estimated at between 7 and 12 per 10000 per day"; the population was estimated to include over $50 \%$ young children (under 12 years). ${ }^{7}$ Much more attention has been given to the Kurds in the north than to the Shi'ites in the south, and it is likely that the number of deaths there is also substantial. The human toll is summarised in the box.

\section{Summary of Iraqi deaths soon after Gulf war

$\begin{array}{ll}\text { Iraqi military deaths } & 100000-120000 \\ \begin{array}{l}\text { Iraqi civilian deaths during war } \\ \text { Iraqi civilian deaths from end of war } \\ \text { to beginning of May }\end{array} & 5000-15000 \\ \begin{array}{l}\text { Iraqi civilian deaths in civil war } \\ \text { Deaths among Kurds and other } \\ \text { refugees }\end{array} & 4000-6000 \\ & 15000-30000\end{array}$

Estimates of deaths among refugees vary widely - on the basis of extensive interviews Greenpeace has estimated a total of 15000 to $30000 .^{1}$ Relief agencies estimate 50000 deaths on the Iraqi-Turkish border alone, in "the disgraceful shambles of the international relief effort," with fewer deaths on the Iranian-Iraqi border due to efficient Iranian organisation. The Centers for Disease Control in Atlanta extrapolated from a population census in one transit camp a minimum of 6700 deaths on the Iraqi-Turkish border from 29 March to 24 May, compared with an expected mortality of 500 under usual conditions. The extent to 
which the experience of the refugees in the transit camp surveyed was representative of the refugees as a whole is not clear. Of deaths, $63 \%$ were in children under 5 years and $74 \%$ were associated with diarrhoea, dehydration, or malnutrition. ${ }^{9}$ Additional to these figures are deaths during the Kurdish and Shi'ite uprisings.

Thus $80-90 \%$ of the civilian casualties occurred after the war ended. In addition, over two million foreign workers have returned to their countries of origin from Iraq and Kuwait, depriving their countries of much needed foreign earnings and returning in many cases to situations of extreme economic impoverishment. As a direct result of the Gulf war 40 low income and middle income countries have suffered the economic equivalent of a natural disaster. The direct cost to these countries-including Ethiopia, Sudan, Mozambique, and Liberia, where millions already face starvation - is over $\$ U S 12 b n$. To this must be added a drop in Third World exports of $\$ 6 \mathrm{bn}$.

There does not seem to be a complete account of Kuwaiti deaths during the war. During its exile the Kuwaiti government stated that 25000 of its citizens were killed or missing. On 20 March, however, Associated Press suggested that several thousand were killed or still unaccounted for. ${ }^{10}$ On 22 April Kuwait protested that 5433 prisoners of war and civilians had still not been released by Iraq. " The report of Physicians for Human Rights (UK) estimated a minimum of 600 Kuwaitis killed by Iraqi occupying forces in Kuwait.

\section{Destruction of infrastructure and the implications for health}

Coalition bombing targeted power stations with such effectiveness that in the immediate postwar period their generating capacity was only $4 \%$ of that available before the war. By May this had risen to just over $20 \%$ of prewar generating capacity. ${ }^{13}$ Repairs to electricity generators have been greatly hampered by the economic embargo. Electricity, sewage and water treatment facilities and distribution systems were also substantially damaged by Coalition forces, with immediate and continuing impact on the health of Iraq's civilian population.

The United Nations' Ahtisaari report corrected a common misperception in the Western media: "The recent conflict has wrought near-apocalyptic results upon the economic infrastructure of what had been, until January 1991, a rather highly urbanised and mechanised society. Now, most means of modern life support have been destroyed or rendered tenuous. Iraq has, for some time to come, been relegated to a preindustrial age, but with all the disabilities of postindustrial dependency on an intensive use of energy and technology."

In 1990 Iraq had a nationwide network of 131 hospitals and 851 community health centres, which provided comprehensive health services to both urban and rural populations. The system reached more than $90 \%$ of the population ${ }^{14}$ and community immunisation programmes reached $95 \%$ of the population. Many hospitals and community health centres were severely damaged, either by the direct effects of the conflict or during the civil disturbances that followed. The Harvard Study Team reported that in Arbill, two months after the war, only five of 42 community health centres were functioning and at Sulaymānìyah only six out of $20 .{ }^{13}$ In Basra only five of 19 community health centres functioned. Those that are open are having to cope with unrealistically large catchment populations. For instance, the Al Batein Community Health Centre in Basra, which normally serves 40000 people, now serves 150000 . Medical facilities lack clean water, electricity, and sewage disposal. Of the 16 functioning hospitals and community health centres that the Harvard Study Team surveyed, $69 \%$ had inadequate sanitation owing to damage to water purification and sewage treatment plants. The lack of electricity has also affected operating theatres and laboratories. There is also a dearth of medicines, intravenous fluids, infant formulas, needles, syringes, and bandages. Stores of heat sensitive vaccines have been depleted because of the lack of electricity.

Raw sewage is being extensively discharged into major rivers. For instance, in Baghdad both sewage treatment plants for the city stopped functioning during the first week of the Gulf war owing to lack of electricity. One of the facilities was completely destroyed by bombing later on. Subsequently the surviving plant resumed operation, but the considerable amount of raw sewage that is discharged into the Tigris is polluting the drinking water in southern Iraq. The collection of rubbish is also reported to have diminished due to a shortage of fuel for trucks. Severe malnutrition is common in children: at least twice as many children with gastroenteritis are being admitted to hospital as before, and of these, twice as many die. ${ }^{\text {s }}$ Typhoid and cholera are now epidemic in many areas, and polio, meningitis, and hepatitis are likely to become more common; the Harvard team estimates conservatively that child mortality has doubled, with a further 80000-200 000 under 5 s expected to die in the coming year in the aftermath of the Gulf war unless health care, sanitation, and food supply improve ( $R$ Moodie, personal communication). Lack of medicines will affect not only children but also those receiving long term treatment for conditions such as diabetes, hypothyroidism, hypertension, and epilepsy. Even taking into account the relative youthfulness of much of Iraq's population of 18 million, those with chronic diseases at risk from lack of drugs are likely to number in the hundreds of thousands.

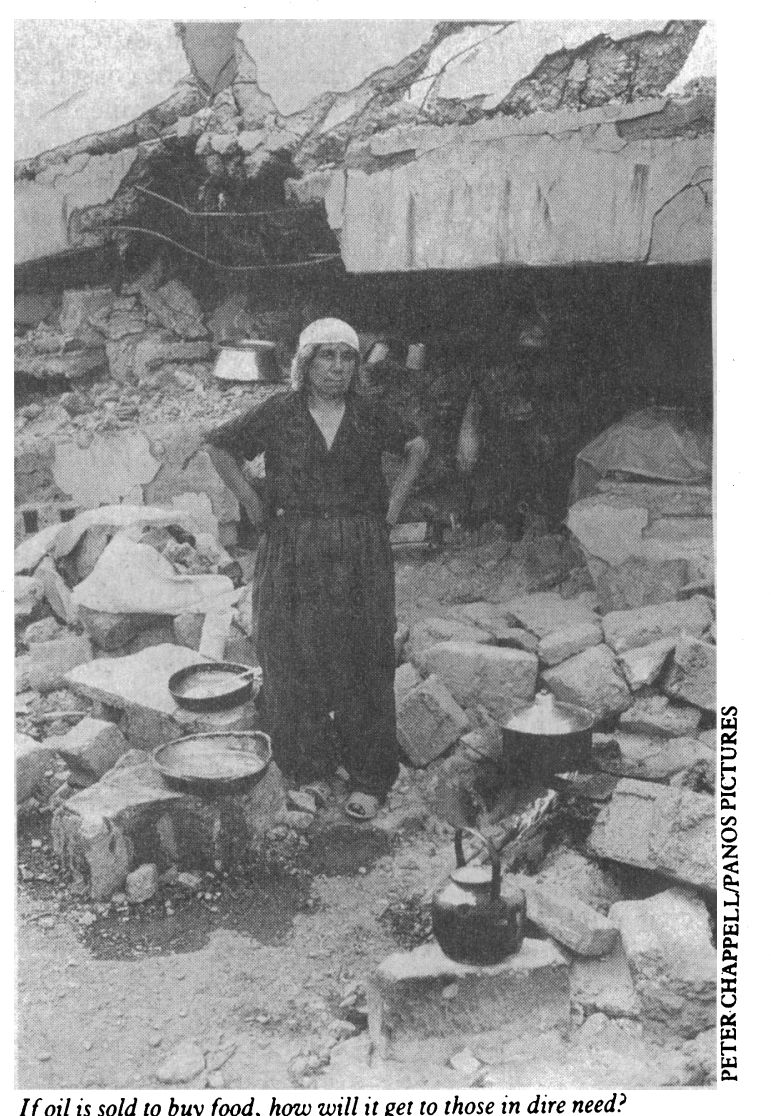




\section{Environmental effects}

Oil released deliberately by Iraqi forces totalled around three million barrels, and possibly as much as four million, perhaps the worst oil spill on record.' The Gulf is a shallow body of water with a rich flora and fauna. Extensive beds of sea grass are vulnerable, as are fish, sea turtles, marine mammals (dugongs and dolphins), birds, and invertebrates. The migration of European species of birds, which is estimated to total over two million, may be threatened. The oil slick may threaten desalination plants and will cause some long term damage to fisheries.

As many as $\mathbf{5 8 0}$ oil wells are set on fire, with many others flowing uncontrollably but not on fire. The fires created a $15000 \mathrm{~km}^{2}$ cloud of smoke and soot which was carried towards the south and south east. At the end of March the World Health Organisation warned people with respiratory difficulties to remain indoors when the smoke plume was overhead, and it is reported that Kuwaiti clinics have seen a sharp rise in patients with respiratory problems, including asthma and bronchitis. The medium term and long term effects of the smoke plume are still not clear. The temperature in the oil fields is considerably lower than in nearby Kuwait City, with sunlight prevented from reaching the ground. On 1 April it was reported that black rain had been detected in the Himalayan region of the Indian Kashmir. There is also concern about acid rain The smoke plume has generally stayed below $3600 \mathrm{~m}$, but could rise higher as summer progresses. The height of the plume will determine the distance it travels. There are varying estimates of the time it will take to put out all the fires. The range of estimates is 2-10 years, and the estimate of the cost to rebuild the oilfields is $\$ 25$ billion. ${ }^{16}$

\section{Human rights}

The Iraqi regime has long been guilty of gross violations of human rights and these certainly continued in Kuwait. Unfortunately, since the reoccupation of Kuwait human rights violations have not stopped; there have been widespread criticisms of Kuwaiti maltreatment (including torture and murder) of Palestinians, Jordanians, and others suspected of being collaborators. The government of Saddam Hussein has a long record of persecution of Kurds and Shi'ites, but the Gulf war has not corrected this-instead, it has provided opportunities for Kuwaiti terrorisation of non-Kuwaitis and for the Iraqi authorities to terrorise large numbers of civilians, prompting massive refugee movements.

\section{Food and medicines}

Iraq historically imports more than $70 \%$ of its food requirements. Hyperinflation has resulted in price increases approaching 1000\% since August 1990, and many families are unable to afford adequate food. Government allocations of staple food items fell from 343000 metric tons per month in September 1990 to 135000 tons in January $1991 .{ }^{15}$ The United Nations' Ahtisaari report of 28 March noted that all staple items were either critically low or completely exhausted. Agricultural production has been severely affected by the war and economic sanctions. Damage to electricity has affected irrigation pumps and there is a lack of fertilisers and spare parts for agricultural machinery. The Ahtisaari report concluded that widespread starvation could become a real possibility if the harvest is far below average.

These disastrous effects of the war itself seem to have been prolonged by the continuation of economic sanctions even after their original objective (the liberation of Kuwait) has been achieved. Between August 1990 and April 1991 less than 10000 metric tons of food was allowed to enter Iraq - this is less than one day's food requirement. ${ }^{15}$ The UN embargo on food was not relaxed until 22 March, nearly a month after the war's end, and then with little immediate effect. A WHO consignment of 35000 metric tons was held up for several weeks in March-April. Although food imports since then have increased, these have been on the level of "essential humanitarian aid" which relief agencies can supply, not the massive and routine food imports needed to restore Iraq's civilian population to prewar standards of public health. It is difficult to see how Iraq can resume its prewar importation of $70 \%$ of its food needs and $75 \%$ of its medical supplies while trade and financial sanctions remain.

American officials are quoted as saying that there is a healthy trade in food and that the West cannot be held responsible because the Iraqi regime is diverting food towards Ba'ath party officials and the army. ${ }^{7}$ The possible element of truth to these allegations does not detract from the fact that Iraq is currently unable to import sufficient food to feed its population. It has been suggested that four to five million tons of food may be needed on an emergency basis when the country's food stockpiles run out sometime between September and January. This would dwarf previous major famine relief programmes such as that in Ethiopia in 1988, which resulted in 850000 tons of food aid being delivered in a year.

Although the UN sanctions resolution 661 (6 August 1990) states that the economic embargo does not include "supplies intended strictly for medical purposes," in reality these medicines are not entering Iraq in sufficient quantity. More than 50 separate consignments of medicines were purchased by the government of Iraq before 1990, yet as of May the supplier countries still refused to forward them to Iraq. ${ }^{16}$ Supplies of vaccines began to run out in late 1990 . Damage to the electricity supply prevents the reestablishment of the cold chain for immunisation. During a recent meeting with Drs Muhammed AlRawi and Rajih Al-Kaabi of Baghdad at a conference in Stockholm of International Physicians for the Prevention of Nuclear War one of us $(\mathrm{AH})$ heard of the lack of medicines and equipment at first hand. Drs AlRawi and Al-Kaabi presented a list of drugs which they said were completely absent from the Iraqi market. This list included chloramphenicol, metronidazole, salbutamol and beclomethasone inhalers, insulin, warfarin, thyroxine, phenytoin, local anaesthetics, and cytotoxics. They also mentioned an urgent need for basic items such as venous cannulae, giving sets, disposable syringes, gloves, and resuscitation equipment. In addition, they spoke about a shortage of 800 nurses caused by the departure of foreign nursing staff. They particularly regretted the loss of contact with medicine in the United Kingdom and stated that around 200 doctors were waiting to complete their FRCS and MRCP examinations; they have also received no copies of the BMF and Lancet since the outbreak of hostilities.

Iraq imported more than $\$ 500 \mathrm{~m}$ worth of medicines annually before the war. Between August 1990 and April 1991 less than one thirtieth of its requirements were met $^{16}$ despite the Coalition's claims that medical supplies have always been exempt from sanctions. In many countries a special licence is required to export medicines to Iraq. Many items required for the proper functioning of a health care system, such as spare parts and equipment are prohibited or allowed only on a case by case basis after application to the UN Security Council. 


\section{Economic Costs}

The Gulf states have borne around $62 \%$ of the total costs of the Gulf conflict. The total contributions to American military costs are nearly $\$ 54 \mathrm{bn}$. Emergency aid packages to countries adversely affected by the Gulf crisis amounted to nearly $\$ 16 \mathrm{bn}$. Kuwait will require $\$ 60-95$ bn for reconstruction and Iraq $\$ 110-200 \mathrm{bn}$. Iraq could take 100 years to pay off its debts if it is forced to pay all the costs of the conflict. The commitments of a rich country like Saudi Arabia exceed its foreign exchange reserves, and the situation is made worse by the fact that it intends to double the size of its armed forces and spend $\$ 14 \mathrm{bn}$ on arms in $1992 .{ }^{18}$ The tragedy of wasted resources is particularly poignant when these sums of money are compared with those needed for international humanitarian activities such as the goals adopted at the World Summit for Children, which require an estimated $\$ 20$ bn dollars a year for their implementation. ${ }^{19}$

\section{Conclusion}

Although accurate estimates of casualties are impossible, it seems likely that about 100000 Iraqi troops were killed, with early civilian deaths amounting to 50000 or more. Thus the ratio of military to immediate civilian deaths is much higher than that in many recent wars. Because of continuing sanctions and damage to infrastructure, however, as well as large numbers of refugees, substantially increased child deaths are likely over the next year, bringing the proportion of civilian deaths more in line with other conflicts since the second world war. Since then the proportion of civilian deaths has risen from around $50 \%$ to about $80 \% .^{20}$ The ratio of civilian to military deaths has increased as weapons have become more destructive and populations more dependent on the complex and vulnerable infrastructure of the modern state.

The Gulf conflict has been seen in narrowly military terms as a victory of Coalition forces, but on closer examination the costs can be seen to be enormous, including millions of refugees, hundreds of thousands dead and injured, serious environmental damage, and economic costs of over $\$ 100 \mathrm{bn}$. The larger and continuing part of this cost falls on those not responsible for Saddam Hussein's deeds, many of whom were already his victims - Kurds, Shi'ites, and the civilian population of Iraq in general. At the time of the Coalition offensive, Kuwait's population of just over two million was reduced to around 700000 , of whom about a third were Kuwaiti nationals ${ }^{12}$; the stated aim of the Coalition forces was to expel Iraqi troops. Thus, many more people were killed or seriously affected by the war than were at risk in Kuwait from the Iraqi regime.

At the time of writing, Kuwait still does not have a democratically elected government, and human rights abuses continue. Sanctions have been rejected by Coalition governments as an effective means of forcing Saddam Hussein to leave Kuwait, but they continue to be employed despite the fact that their principal impact now is on children and the chronically sick - the most vulnerable members of society, who are unlikely to have any perceptible influence on the course of events in Iraq. Although in March the UN sanctions committee adopted a no objection procedure for the importation of some equipment such as small generators and water purification equipment, ${ }^{21}$ it has recently refused Iraq's request to export $\$ 1.5$ bn worth of oil to buy food following the Baghdad government's attempts to hide its nuclear weapons programme. A recent conference discussed the possibility of a fifth Geneva convention on the protection of the environ- ment at the time of armed conflict ${ }^{1}$; further consideration needs to be given to the protection of children and other vulnerable groups from the effects of ill considered sanctions. Sanctions may be of use in changing the regime in the long term, but they should concentrate primarily on preventing military recovery and avoid focusing on children and the chronically sick.

Much greater efforts should be made to obtain more accurate estimates of casualties from the Gulf war so that the total impact can be more accurately ascertained. Objective assessments of the adverse effects of the Gulf conflict are required so that they can better inform policy makers in the future should they be faced with a similar situation. Analysis of the medical, environmental, and economic effects based on currently available information suggests that the adverse effects already exceed by a considerable degree any resulting benefits.

Health professionals can play an important part in reducing the human costs of the Gulf conflict by urging Western governments to abandon those sanctions that inflict further suffering on innocent civilians and by establishing contact with professional colleagues in Iraq and Kuwait to support them in their efforts to reconstruct health services and return to their previously high level of health care.

Iraqi doctors can be contacted through Dr Mahmoud Huneidi of Jordanian Physicians for the Prevention of War, Jordan Medical Association, PO Box 915, Amman, Jordan, or Dr Nabih Muammar, PO Box 2464, Amman, Jordan. The background material on which this paper is based is described in more detail in MET Report: Counting the Human Cost of the Gulf War, available from The Medical Educational Trust, 601 Holloway Rd, London N19 4DJ, price $£ 2$ including postage.

We thank Drs Eric Hoskins and Rob Moodie for their helpful advice.

1 Arkin WM, Durrant D, Cherni M. On impact: modern warfare and the environment: a case study of the Gulf war. Washington, DC: Greenpeace, 1991.

2 Doyle L. Triumphant army marches to the rumble of debate. Independent 1991 June 8:10.

3 United Nations. Report to the Secretary General on humanitarian needs in Kuwait and Iraq in the immediate post-crisis environment by a mission led by Mr Marr Ahtisaari, Under Secretary General for Administration and Management, 28 March 1991. Geneva: United Nations, 1991.

4 Clark R. Iraqi civilians bear brunt of bombing. War Report 1991 February

23:1.
5 Randal JC. Kurds puts civilian casualties at 3000 . International Herald Tribune 1991 February 11:3.

6 Doyle L. Nutritionists find no famine in Iraq. Independent 1991 July 11:13.

7 United Nations. Middle East/Persian Gulf-refugee emergency situation and requirements. Geneva: United Nations, 1991. (Situation report No 1.)

8 Seaman J. What's wrong with the international relief system? London: Save The Children Fund, 1991.

9 Centers for Disease Control. Public health consequences of acute displacemen of Iraqi citizens-March-May 1991. Mortality of Morbidity Weekly Review, 1991;40:443-6.

10 Associated Press. Kuwait seeks hanging for 600. Current News Early Bird, 199 March 20:16.

11 UN sets up body to destroy Iraq's heavy weapons. United Press International 1991 April 23.

12 Physicians for Human Rights (UK). Kuwait 1991: human rights abuses and effects on the health care system during and after the Iraqi occupation. Dundee: University Department of Forensic Medicine, Royal Infirmary, 1991.

13 Harvard University School of Public Health. Harvard study team report: public health in Iraq after the Gulf War. Boston: Harvard University School of Public Health, 1991

14 United Nations Children's Fund, World Health Organisation. 1990 national survey on vaccination, diarrhoea and child and maternal diseases in Iraq. Geneva: United Nations/WHO, 1990

15 Hoskins E, Bauman C, Harding S. Gulf Peace Team special mission to Iraq health assesement team. London: Gulf Peace Team, 1991. (Available from 7

16 Kuwaiti oil fires could burn for years, reconstruction director says. United Press International (New York) 28 February 1991.
Priti

17 Doyle L. Iraq Facing famine if UN sanctions stay. Independent 1991 July 3:9.

17 Doyle L. Iraq Facing famine if UN sanctions stay. Independent 1991 July 3:9. No 5. Oxford: Oxford Research Group, 1991:21-7.

19 United Nations Children's Fund. The state of the world's children, 1991 Oxford: Oxford University Press, 1991.

20 Sivard RL. World military and social expenditures 1989. Washington: World Priorities Inc, 1990:22-3.

21 House of Commons official report (Hansard) 1991 July 3;194:col 378. (No 137.)

(Accepted 16 fuly 1991) 